\title{
Thermodynamic Properties of Strontium-Bismuth Alloys Determined by Electromotive Force Measurements
}

Nathan Smith ${ }^{1}$, Timothy Lichtenstein ${ }^{1}$, Jarrod Gesualdi ${ }^{1}$, Kuldeep Kumar ${ }^{1}$, Hojong Kim ${ }^{1 *}$

${ }^{1}$ Materials Science and Engineering, The Pennsylvania State University, 406 Steidle Building, University Park, PA 16802, United States of America

Author E-mail addresses:

nds174@psu.edu, tv15297@psu.edu,jqg5465@psu.edu, kxk1023@psu.edu, huk29@psu.edu Corresponding Author:

*Email: huk29@psu.edu. Tel: 814-865-3117. Fax: 814-865-2917

KEYWORDS: Strontium-bismuth alloys, Emf method, Sr-Bi phase diagram, Thermodynamic properties 


\section{ABSTRACT}

The thermodynamic properties of $\mathrm{Sr}-\mathrm{Bi}$ alloys were determined by electromotive force (emf) measurements to evaluate the viability of liquid bismuth metal as a medium for separating alkali/alkaline-earth fission products from molten salt electrolyte. A $\operatorname{Sr}(\mathrm{s})\left|\mathrm{CaF}_{2}-\mathrm{SrF} \mathrm{F}_{2}\right| \operatorname{Sr}(\mathrm{in} \mathrm{Bi})$ cell was used to measure emf values at $748-1023 \mathrm{~K}$ for thirteen $\mathrm{Sr}-\mathrm{Bi}$ alloys at mole fractions $0.05 \leq x_{\mathrm{Sr}} \leq 0.75$. Activity values of strontium in bismuth were determined at $788 \mathrm{~K}, 888 \mathrm{~K}$, and $988 \mathrm{~K}$ as well as the partial molar entropy and enthalpy at each composition. Reproducible emf values within $\pm 5 \mathrm{mV}$ were obtained up to $x_{\mathrm{Sr}}=0.35$ during cooling-heating cycle. At higher mole fractions $\left(x_{\mathrm{Sr}} \geq 0.40\right)$, the emf values exhibited increased hysteresis during the thermal cycles due to the strong tendency of the alloys to form meta-stable phases. The non-equilibrium phase behavior of $\mathrm{Sr}-\mathrm{Bi}$ alloys was verified by X-ray diffraction (XRD), differential scanning calorimetry (DSC) and microstructural analyses. Compared to the existing equilibrium phase diagram, two additional phases of $\mathrm{Sr}_{2} \mathrm{Bi}_{3}$ and $\mathrm{Sr}_{4} \mathrm{Bi}_{3}$ were identified and discussed. Liquid-state

solubility of $\mathrm{Sr}$ was $15-40 \mathrm{~mol} \%$ at $788-988 \mathrm{~K}$ and the activity values were as low as $10^{-13}$ at $788 \mathrm{~K}$, implying strong chemical interactions between $\mathrm{Sr}$ and $\mathrm{Bi}$. 


\section{INTRODUCTION}

Electrochemical separation using molten salt electrolytes (e.g., $\mathrm{LiCl}-\mathrm{KCl}$ ) is currently one of the most promising techniques for separating uranium and transuranics from metallic used nuclear fuels [1]. However, the process has the inevitable consequence of accumulating alkali/alkaline-earth fission products in the molten salt electrolyte because alkali/alkaline-earth metals ( $\mathrm{Ba}, \mathrm{Sr}$, and $\mathrm{Cs}$ ) have the strongest tendency to oxidize during electrolysis. Periodic replacement of the electrolyte containing these fission products results in chloride wastes that can limit the development of a ceramic wasteform for long-term disposal and increase the volume of nuclear waste [2]. In addition, the alkali/alkaline fission products $\mathrm{Sr}$ and Cs pose serious environmental challenges as they have short half-lives (around 30 years) and highest heat densities [3]. In our previous work, the separation of barium from quaternary $\mathrm{BaCl}_{2}-\mathrm{LiCl}_{-} \mathrm{CaCl}_{2}-$ $\mathrm{NaCl}$ (16-29-35-20 mol\%) electrolyte was achieved due to the extremely low thermodynamic activity of $\mathrm{Ba}$ in the liquid $\mathrm{Bi}$ electrode compared to $\mathrm{Li}, \mathrm{Ca}$, and $\mathrm{Na}$, implying strong atomic interactions between $\mathrm{Ba}$ and $\mathrm{Bi}$ [4]. In efforts to separate radiotoxic $\mathrm{Sr}$ species from molten salt electrolyte, the thermodynamic properties of Sr-Bi alloys at 748-1023 K were examined using electromotive force (emf) techniques to evaluate the viability of using liquid bismuth electrodes for the separation of Sr.

Constructing an electrochemical cell to effectively measure emf values for $\mathrm{Sr}-\mathrm{Bi}$ alloys can be technically challenging due to (i) the high reactivity of pure $\mathrm{Sr}$ as well as $\mathrm{Sr}-\mathrm{Bi}$ alloys which can degrade the electrolytes or cell components during emf measurements, and (ii) the high melting temperatures of pure $\operatorname{Sr}\left(T_{\mathrm{m}, \mathrm{Sr}}=1042 \mathrm{~K}\right)$ and $\mathrm{Sr}$-Bi alloys $\left(T_{\text {liquidus }}\right.$ up to $\left.1218 \mathrm{~K}\right)$ [5]. In recent studies, solid-state $\mathrm{CaF}_{2}$ electrolyte has been utilized in determining the thermodynamic properties of $\mathrm{Ca}-\mathrm{Bi}, \mathrm{Ca}-\mathrm{Sb}$, and $\mathrm{Ca}-\mathrm{Mg}$ alloys at 723-1100 K [6-8], employing 
the high stability of $\mathrm{CaF}_{2}$ electrolyte in emf measurements of calcium alloys. Delcet and Egan also determined the emf values of $\mathrm{Ca}-\mathrm{Ag}$ and $\mathrm{Ca}-\mathrm{In}$ alloys using single-crystal $\mathrm{CaF}_{2}$ at $1073 \mathrm{~K}$ via coulometric titration techniques and derived thermodynamic activity values of calcium [9]. The solid-state $\mathrm{CaF}_{2}$ is well known to have substantial ionic conductivity $\left(1.5 \times 10^{-3} \mathrm{~S} \mathrm{~cm}^{-1}\right.$ at $1073 \mathrm{~K})$, suitable for emf measurements [10,11].

In the present study, the investigation of $\mathrm{Sr}-\mathrm{Bi}$ alloys required using $\mathrm{CaF}_{2}-\mathrm{SrF}_{2}$ (97-3 mol\%) instead of the pure $\mathrm{CaF}_{2}$ electrolyte to account for the change in electroactive species. According to the analysis of standard electrode potentials in the fluoride system at $873 \mathrm{~K}$ (Figure 1a), $\mathrm{CaF}_{2}$ is more stable than $\mathrm{SrF}_{2}$ and thus, strontium ions are expected to be the most electroactive species in the $\mathrm{CaF}_{2}-\mathrm{SrF}_{2}$ binary electrolyte. In contrast, $\mathrm{SrCl}_{2}$ is more stable than $\mathrm{CaCl}_{2}$ in the chloride system (Figure $1 \mathrm{~b}$ ) and thus, calcium becomes the most electroactive species, invalidating the stable emf measurements of Sr-based alloys in $\mathrm{CaCl}_{2}-\mathrm{SrCl}_{2}$ electrolyte due to the side reactions (e.g., $\mathrm{Sr}+\mathrm{CaCl}_{2}=\mathrm{SrCl}_{2}+\mathrm{Ca}, \Delta_{\mathrm{r}} G=-28.9 \mathrm{~kJ}$ at $873 \mathrm{~K}$ ) [12].

\section{[Figure 1]}

The temperature-dependent thermodynamic properties of Sr-Bi alloys were investigated using the following electrochemical cell:

$$
\operatorname{Sr}(\mathrm{s})\left|\mathrm{CaF}_{2}-\mathrm{SrF}_{2}\right| \operatorname{Sr}(\text { in } \mathrm{Bi})
$$

, where pure strontium acts as the reference electrode (RE), solid $\mathrm{CaF}_{2}-\mathrm{SrF}_{2}(97-3 \mathrm{~mol} \%)$ as the electrolyte, and Sr-Bi alloys as working electrodes (WE). In this electrochemical cell, the halfcell reactions are

$$
\text { WE: } \mathrm{Sr}^{2+}+2 \mathrm{e}^{-}=\operatorname{Sr}(\text { in Bi })
$$




$$
\mathrm{RE}: \mathrm{Sr}^{2+}+2 \mathrm{e}^{-}=\operatorname{Sr}(\mathrm{s})
$$

, and the overall cell reaction is

$$
\operatorname{Sr}(\mathrm{s})=\operatorname{Sr}(\mathrm{in} \mathrm{Bi})
$$

The change in partial molar Gibbs energy of strontium, $\Delta \bar{G}_{\mathrm{Sr}}$, for this reaction is given by

$$
\Delta \bar{G}_{\mathrm{Sr}}=\bar{G}_{\mathrm{Sr}(\mathrm{in} \mathrm{Bi})}-G_{\mathrm{Sr}(\mathrm{s})}^{0}=R T \ln a_{\mathrm{Sr}}
$$

, where $\bar{G}_{\mathrm{Sr}(\mathrm{in} \mathrm{Bi})}$ is the partial molar Gibbs energy of strontium in bismuth, $G_{\mathrm{Sr}(\mathrm{s})}^{0}$ is the free energy of pure strontium, $R$ is the ideal gas constant, $T$ is the temperature, and $a_{\mathrm{Sr}}$ is the activity of strontium in bismuth. By applying the Nernst equation to Eq. (4), the change in partial molar Gibbs energy of strontium in a given bismuth alloy (and thus activity) is directly related to the cell emf $E_{\text {cell: }}$

$$
E_{\mathrm{cell}}=-\frac{\Delta \bar{G}_{\mathrm{Sr}}}{z F}=-\left(\frac{R T}{z F}\right) \ln a_{\mathrm{Sr}}
$$

, where $F$ is the Faraday constant and $z$ is the number of electrons transferred in the reaction $(z=$ 2).

\section{EXPERIMENTAL}

\subsection{Electrochemical cell components and assembly}

Solid $\mathrm{CaF}_{2}-\mathrm{SrF}_{2}$ (97-3 mol\%) electrolyte was prepared by ball-milling $350 \mathrm{~g}$ of highpurity $\mathrm{CaF}_{2}$ (Alfa Aesar, Stock No. 11055), $16.9 \mathrm{~g}$ of high-purity $\mathrm{SrF}_{2}$ (Sigma Aldrich, Stock No. 450030), and $25 \mathrm{~g}$ of polyvinyl alcohol binder (Sigma Aldrich, Stock No. 341584) in isopropanol for $24 \mathrm{~h}$. The mixture was dried in air for $24 \mathrm{~h}$ and approximately $130 \mathrm{~g}$ of powder was taken and 
uniaxially pressed at $30 \mathrm{MPa}$ into a pellet $75 \mathrm{~mm} \times 17 \mathrm{~mm}$ in diameter and thickness. Seven wells (each with $11.2 \mathrm{~mm} \times 12 \mathrm{~mm}$ in diameter and depth) were drilled into the pellet with one well in the center and six wells evenly spaced $25.4 \mathrm{~mm}$ away from the center (Figure 2a). Similarly, seven caps were fabricated from $4 \mathrm{~g}$ of the mixture $(19 \mathrm{~mm}$ x $10 \mathrm{~mm}$ in diameter and height) with a $1.1 \mathrm{~mm}$ hole drilled through the center. These green pellets were then fired in air at $393 \mathrm{~K}$ for $12 \mathrm{~h}$ to remove moisture, $823 \mathrm{~K}$ for $12 \mathrm{~h}$ to burn away the polyvinyl alcohol binder, and $1273 \mathrm{~K}$ for $3 \mathrm{~h}$ to sinter. The sintered $\mathrm{CaF}_{2}-\mathrm{SrF}_{2}$ electrolyte was confirmed to have formed a single-phase solid solution (fluorite phase) by an x-ray diffractometer (XRD) as shown in Figure $2 b$.

\section{[Figure 2]}

Strontium-bismuth alloys at specific compositions were fabricated from bismuth pieces (Sigma Aldrich, Stock No. 556130) and strontium ingot (Sigma Aldrich, Stock No. 343730) using an arc melter (MAM1, Edmund Buhler $\mathrm{GmbH}$ ) under argon atmosphere. The alloys were machined into a cylindrical shape $(10 \mathrm{~mm} \times 7 \mathrm{~mm}$ in diameter and thickness $)$ with a $1.1 \mathrm{~mm}$ center hole for insertion of the electrical lead wire (tungsten).

Final assembly of the electrochemical cell was performed in a glovebox under an inert argon environment $\left(\mathrm{O}_{2}\right.$ concentration $\left.<0.5 \mathrm{ppm}\right)$ to mitigate the rapid oxidation of $\mathrm{Sr}$ and $\mathrm{Sr}-\mathrm{Bi}$ alloys. The $\mathrm{CaF}_{2}-\mathrm{SrF}_{2}$ electrolyte was placed in an alumina crucible $(8.2 \mathrm{~cm}$ diameter $\times 3.0 \mathrm{~cm}$ height $)$ and tungsten wires $(1 \mathrm{~mm} \times 46 \mathrm{~cm}$ in diameter and length $)$ were inserted into alumina tube sheaths, sealed at the top with epoxy, passed through the stainless steel test chamber, through the $\mathrm{CaF}_{2}-\mathrm{SrF}_{2}$ caps, and into the electrodes. The caps were installed to minimize the contamination of alloys during the measurements by physically blocking the vapor-phase transport of strontium. 


\subsection{Emf measurements}

The test chamber was then sealed, removed from the glovebox, loaded into a crucible furnace, and evacuated to $\sim \mathrm{Pa}$. The test chamber was heated at $373 \mathrm{~K}$ for $12 \mathrm{~h}$, at $543 \mathrm{~K}$ for 12 $\mathrm{h}$ under vacuum to remove residual moisture and oxygen, purged three times with high purity argon, and finally heated to $1023 \mathrm{~K}$ under flowing argon $\left(\sim 10 \mathrm{~mL} \mathrm{~min}{ }^{-1}\right)$ atmosphere to melt the electrodes and establish electrical contact with the tungsten wires.

Emf measurements were performed by measuring the potential difference between the reference electrode and each working electrode (Sr-Bi alloys) sequentially in $180 \mathrm{~s}$ intervals during thermal cycles using a potentiostat-galvanostat (Autolab PGSTAT302N, Metrohm AG). Emf data were collected throughout a cooling and reheating cycle between $1023 \mathrm{~K}$ and $748 \mathrm{~K}$ in $25 \mathrm{~K}$ increments. The cell temperature was held constant at each increment for $1.5 \mathrm{~h}$ to reach thermal and electrochemical equilibria and ramped at $\pm 5 \mathrm{~K} \mathrm{~min}^{-1}$ between increments. The cell temperature was measured using a thermocouple (ASTM type-K) located at the center of the electrolyte, and thermocouple data acquisition system (NI 9211, National Instruments).

\subsection{Characterization of Sr-Bi alloys}

Crystal structures of the Sr-Bi alloys were characterized using an X-ray diffractometer (XRD, PANalytical Empryean). For equilibrium phase determination, Sr-Bi alloys were annealed at $\sim 15 \mathrm{~K}$ below their solidus temperatures for $24 \mathrm{~h}$. Samples were prepared by grinding Sr-Bi alloys into a fine powder using a mortar and pestle in a glovebox under inert argon atmosphere. The powder samples were coated with mineral oil in order to minimize the oxidation of the alloys during the measurements. A broad amorphous background from mineral 
oil was present in the XRD spectra at low angles $\left(10^{\circ} \leq 2 \theta \leq 20^{\circ}\right)$, but was subtracted to facilitate the identification of crystalline phase peaks of Sr-Bi alloys.

The morphology and microstructure analysis of the annealed alloys was performed using scanning electron microscope (SEM, FEI Quanta 200) fitted with energy dispersive spectroscopy (EDS) capabilities to identify the phases and their compositions. Samples were mounted in epoxy, ground, and polished with emery papers of 100-2000 grit sizes using isopropanol.

Differential scanning calorimetry (DSC) and thermal gravimetric (TG) analyses were performed using a thermal analyzer (Netzsch Instruments, STA 449 F3 Jupiter) to detect phase transition temperatures of $\mathrm{Sr}-\mathrm{Bi}$ alloys to complement the phase behavior determined by the emf techniques. About 20-50 mg of each annealed alloy sample was placed in an alumina crucible with a thin tungsten foil interlayer ( $4.8 \mathrm{~mm}$ diameter $\times 0.1 \mathrm{~mm}$ thickness) that acted as a reaction barrier between the $\mathrm{Sr}-\mathrm{Bi}$ alloy and alumina crucible. Thermal analyses were conducted at multiple scan rates $\left(7-20 \mathrm{~K} \mathrm{~min}^{-1}\right)$ and the phase transition temperature was determined based on onset temperatures at various scan rates by extrapolating the onset temperatures to the scan rate of $0 \mathrm{~K} \mathrm{~min}^{-1}$ [13]. The Sr-Bi alloys with $x_{\mathrm{Sr}} \geq 0.35$ were found to damage platinum parts of TGDSC sensor, possibly due to the vapor phase transport of Sr vapors, and were excluded for further measurements.

\section{RESULTS AND DATA ANALYSIS}

\subsection{Emf Measurements}

The use of pure strontium metal as reference electrode caused rapid degradation of the solid-state $\mathrm{CaF}_{2}-\mathrm{SrF}_{2}$ electrolyte, resulting in a poor reproducibility of the emf measurements as well as a decline in reference electrode stability. Instead, a less reactive $\mathrm{Sr}-\mathrm{Bi}$ alloy (mole 
fraction, $x_{\mathrm{Sr}}=0.10$ ) was employed as the reference electrode in emf measurements of various alloy compositions using a $\operatorname{Sr}-\mathrm{Bi}\left(x_{\mathrm{Sr}}=0.10\right)\left|\mathrm{CaF}_{2}-\mathrm{SrF}_{2}\right| \operatorname{Sr}(\mathrm{in} \mathrm{Bi})$ cell, in a manner similar to Newhouse et al. [8]. The choice the Sr-Bi alloy $x_{\mathrm{Sr}}=0.10$ was advantageous because this alloy composition (1) experiences no phase changes at 700-1023 K, resulting in a linear thermal emf $\left(\mathrm{d} E_{\text {cell }} / \mathrm{d} T\right)$; (2) produced highly reproducible emf values for various $\mathrm{Sr}-\mathrm{Bi}$ alloys during the thermal cycle; and (3) their potential difference remained less than $\pm 5 \mathrm{mV}$ throughout the emf measurements, implying an excellent stability as a reference electrode (Figure 3a). In separate experiments, the electrode potential of the $\mathrm{Sr}-\mathrm{Bi}$ alloy $x_{\mathrm{Sr}}=0.10$ was determined against pure $\mathrm{Sr}$ using a $\operatorname{Sr}(\mathrm{s})\left|\mathrm{CaF}_{2}-\mathrm{SrF}_{2}\right| \operatorname{Sr}-\mathrm{Bi}\left(x_{\mathrm{Sr}}=0.10\right)$ cell (Figure 3b). Using the linear fit of this measurement at $x_{\mathrm{Sr}}=0.10$ (Figure $3 \mathrm{~b}$ ), the emf values of $\mathrm{Sr}-\mathrm{Bi}$ alloys $E_{\text {cell }}$ are reported relative to pure Sr metal.

\section{[Figure 3]}

The variation of emf with temperature and composition for $\mathrm{Sr}-\mathrm{Bi}$ alloys $\left(x_{\mathrm{Sr}}=0.05-0.75\right)$ is displayed in Figure 4a-c, obtained upon cooling and reheating the electrochemical cells. In general, the emf values were in close agreement between the cooling and heating with less than a $5 \mathrm{mV}$ difference up to $x_{\mathrm{Sr}}=0.30$. In Figure $4 \mathrm{a}$, the emf varies linearly with respect to temperature and increases as $x_{\mathrm{Sr}}$ decreases above the liquidus (liquid = liquid $+\mathrm{SrBi}_{3}(\mathrm{~s})$ ); below the liquidus, the activity of strontium does not change with composition and the emf values collapse onto the same line. In Figure 4b, mole fraction $x_{\mathrm{Sr}}=0.30$ exhibits two phase transitions, a liquidus (liquid $=$ liquid $+\mathrm{Sr}_{2} \mathrm{Bi}_{3}$ ) at $908 \mathrm{~K}$ and a solidus (liquid $+\mathrm{Sr}_{2} \mathrm{Bi}_{3}=\mathrm{SrBi}_{3}+\mathrm{Sr}_{2} \mathrm{Bi}_{3}$ ) at $843 \mathrm{~K}$.

Emf values of alloys with high strontium content $\left(0.35 \leq x_{\mathrm{Sr}} \leq 0.75\right)$ exhibited increased hysteresis between the heating-cooling cycles up to a $25 \mathrm{mV}$ difference possibly due to the 
increased reactivity. For this reason, emf data for high Sr alloys $\left(x_{\mathrm{Sr}} \geq 0.35\right)$ were collected from the first cooling cycle only (Figure 4b-c). Mole fraction $x_{\mathrm{Sr}}=0.45$ exhibited a solidus transition (liquid $+\mathrm{Sr}_{11} \mathrm{Bi}_{10}=\mathrm{Sr}_{2} \mathrm{Bi}_{3}+\mathrm{Sr}_{11} \mathrm{Bi}_{10}$ ) at $908 \mathrm{~K}$ (Figure $4 \mathrm{~b}$ ); mole fraction $x_{\mathrm{Sr}}=0.55$ exhibited a solidus phase transition (liquid $+\mathrm{Sr}_{4} \mathrm{Bi}_{3}=\mathrm{Sr}_{11} \mathrm{Bi}_{10}+\mathrm{Sr}_{4} \mathrm{Bi}_{3}$ ) at $\sim 985 \mathrm{~K}$ (Figure 4c). The transition reactions were inferred based on the observed crystal structures at each composition, which will be discussed later in section 3.2. It should be noted that the observed crystal structures of the $\mathrm{Sr}_{2} \mathrm{Bi}_{3}$ and $\mathrm{Sr}_{4} \mathrm{Bi}_{3}$ phases are well reported in the database [14,15], but not included in the most recent $\mathrm{Sr}-\mathrm{Bi}$ equilibrium phase diagrams. It is probable that these structures exist as metastable phases in the present study.

\section{[Figure 4]}

The change in the partial molar entropy of strontium, $\Delta \bar{S}_{\mathrm{Sr}}$, was calculated from linear fits of the measured emf data in Figure 4a-c using the thermodynamic relation:

$$
\Delta \bar{S}_{\mathrm{Sr}}=-\left(\frac{\partial \Delta \bar{G}_{\mathrm{Sr}}}{\partial T}\right)_{P}=z F\left(\frac{\partial E_{\mathrm{cell}}}{\partial T}\right)_{P} .
$$

Similarly, the change in the partial molar enthalpy, $\Delta \bar{H}_{\mathrm{Sr}}$, was calculated using the GibbsHelmholtz relation:

$$
\Delta \bar{H}_{\mathrm{sr}}=-T^{2}\left(\frac{\partial\left(\Delta \bar{G}_{\mathrm{sr}} / T\right)}{\partial T}\right)_{P}=z F T^{2}\left(\frac{\partial\left(E_{\mathrm{cell}} / T\right)}{\partial T}\right)_{P}=-z F\left(\frac{\partial\left(E_{\mathrm{cel}} / T\right)}{\partial(1 / T)}\right) .
$$

As shown in Figure 5 for alloys $x_{\mathrm{Sr}}=0.05-0.15$, the change in partial molar enthalpy was estimated based on the slopes by plotting $E_{\text {cell }} T$ versus $1 / T$. The estimated partial molar quantities as well as the linear fits of temperature-dependent emf values are summarized in Table 1. 


\section{[Figure 5]}

\section{[Table 1]}

Using the Nernst equation, the activity of $\mathrm{Sr}$ in $\mathrm{Bi}, a_{\mathrm{Sr}}$, was calculated for specific temperatures of $788 \mathrm{~K}, 888 \mathrm{~K}$, and $988 \mathrm{~K}$ using the measured emf values:

$$
\ln a_{\mathrm{Sr}}=-\frac{z F E_{\mathrm{cell}}}{R T} .
$$

The excess partial molar Gibbs energy of $\mathrm{Sr}, \bar{G}_{\mathrm{Sr}}^{E}$, was then calculated from the activity data:

$$
\bar{G}_{\mathrm{Sr}}^{E}=R T \ln \gamma_{\mathrm{Sr}}=R T\left(\ln a_{\mathrm{Sr}}-\ln x_{\mathrm{Sr}}\right)
$$

, where $\gamma_{\mathrm{Sr}}$ is the activity coefficient. The results of emf values, natural log of the activity, and the excess partial molar Gibbs energy are summarized in Table 2 and are presented graphically in Figure 6 at $888 \mathrm{~K}$.

\section{[Table 2]}

\section{[Figure 6]}

Figures 6a displays the emf values as a function of strontium mole fraction with the phase compositions of each intermetallic compound as well as liquidus composition at $888 \mathrm{~K}$. In the two-phase region (liquid $+\mathrm{Sr}_{2} \mathrm{Bi}_{3}$ ) at $0.26<x_{\mathrm{Sr}}<0.40$, the emf is nearly constant because chemical potential (or activity) of Sr becomes invariant with respect to $x_{\mathrm{Sr}}$ in two-phase regions (Figure 6a-b). However, in the two-phase region $\left(\mathrm{Sr}_{2} \mathrm{Bi}_{3}+\mathrm{Sr}_{11} \mathrm{Bi}_{10}\right)$ at $0.40<x_{\mathrm{Sr}}<0.52$, the different emf values were obtained, indicating non-equilibrium phase behavior. In the $\mathrm{Sr}-\mathrm{Bi}$ system, a large excess partial molar Gibbs energy (as low as $-176 \mathrm{~kJ} \mathrm{~mol}^{-1}$ at $x_{\mathrm{Sr}}=0.05$ ) was obtained, indicating a highly non-ideal solution behavior due to the strong chemical interactions between $\mathrm{Sr}$ and $\mathrm{Bi}$ (Figure 6c). 
According to the equilibrium phase diagram [5], we anticipate that the emf values will approach zero in the two-phase composition domain $\left(\mathrm{Sr}_{2} \mathrm{Bi}+\mathrm{Sr}\right)$ at $x_{\mathrm{Sr}}>0.67$ due to the presence of pure strontium phase, as observed in the proxy Ca-Bi system [6]. However, the emf value at $x_{\mathrm{Sr}}=0.75$ remained at $\sim 0.75 \mathrm{~V}$ versus pure Sr (Figure 6a). This discrepancy was found to be due to the formation of meta-stable phases at this composition, and the alloy $x_{\mathrm{Sr}}=0.75$ was comprised of $\mathrm{Sr}_{2} \mathrm{Bi}, \mathrm{Sr}_{5} \mathrm{Bi}_{3}$, and $\mathrm{Sr}_{4} \mathrm{Bi}_{3}$ without pure $\mathrm{Sr}$ phase.

\subsection{Structural characterization and meta-stable phases}

Crystal structures of known phases in the Sr-Bi system are summarized in Table 3 [1416]. X-ray diffraction patterns for Sr-Bi alloys are presented in Figure 7. In general, multiple meta-stable phases were present in Sr-Bi alloy systems at mole fractions $x_{\mathrm{Sr}} \geq 0.25$, which may explain the increased hysteresis in the emf measurements during the cooling-heating cycle as well as unusually high emf values at high strontium concentrations $\left(x_{\mathrm{Sr}}>0.67\right)$.

\section{[Table 3]}

\section{[Figure 7]}

Figure $7 \mathrm{a}$ indicates the presence of bismuth phase $(R \overline{3} \mathrm{~m})$ up to $x_{\mathrm{Sr}}=0.40$ although the equilibrium phase diagram predicts its stability only up to $x_{\mathrm{Sr}}=0.25[5,17]$. Further annealing at $\sim 15 \mathrm{~K}$ below the solidus temperature for $x_{\mathrm{Sr}}=0.40\left(T_{\text {solidus }}=840 \mathrm{~K}\right)$ was performed to remove the meta-stable $\mathrm{Bi}$ phase, but only a slight reduction in the intensity of Bi phase was observed even after $168 \mathrm{~h}$ of annealing, implying that much longer annealing time may be necessary to achieve equilibrium phases. The presence of the $\mathrm{Sr}_{2} \mathrm{Bi}_{3}(P n n a)$ and $\mathrm{Sr}_{4} \mathrm{Bi}_{3}(I \overline{4} 3 d)$ phases was evident as shown in Figure 7b. For instance, mole fraction $x_{\mathrm{Sr}}=0.65$ is expected to be in two- 
phase equilibrium $\left(\mathrm{Sr}_{5} \mathrm{Bi}_{3}\right.$ and $\mathrm{Sr}_{2} \mathrm{Bi}$ ) [5,17], however, this alloy composition was found to be comprised of three phases $\left(\mathrm{Sr}_{5} \mathrm{Bi}_{3}, \mathrm{Sr}_{2} \mathrm{Bi}\right.$, and $\left.\mathrm{Sr}_{4} \mathrm{Bi}_{3}\right)$ via XRD and SEM/EDS analyses.

Notably absent from the XRD analysis was the presence of pure Sr phase peaks at $x_{\mathrm{Sr}}>$ 0.67. Mole fractions $x_{\mathrm{Sr}}=0.75$ and 0.80 were comprised of $\mathrm{Sr}_{2} \mathrm{Bi}, \mathrm{Sr}_{4} \mathrm{Bi}_{3}$ and $\mathrm{Sr}_{5} \mathrm{Bi}_{3}$ (Figure 7b), deviating from the equilibrium phase behavior $\left(\mathrm{Sr}_{2} \mathrm{Bi}\right.$ and $\left.\mathrm{Sr}\right)[5,17]$. These phase analyses explain the abnormally high emf values $0.57-0.80 \mathrm{~V}$ at $x_{\mathrm{Sr}}=0.75$ (see Figure $4 \mathrm{c}$ and Figure 6a) due to the formation of meta-stable phases in emf measurements.

The presence of meta-stable phases at selected compositions was also investigated through microstructural analysis of the Sr-Bi alloys using SEM/EDS. For example, a backscattered SEM image obtained from $x_{\mathrm{Sr}}=0.25$ confirmed the formation of three distinct phases of $\mathrm{Bi}, \mathrm{SrBi}_{3}$, and $\mathrm{Sr}_{2} \mathrm{Bi}_{3}$ based on the chemical analysis by EDS at each phase (Figure 8). The SEM/EDS results agree the with XRD analysis, although this alloy composition is expected to form a single-phase line compound of $\mathrm{SrBi}_{3}$. Our structural phase analyses by XRD and SEM/EDS suggest that Sr-Bi alloys exhibit a strong tendency to form various meta-stable phases.

\section{[Figure 8]}

\subsection{Thermal analysis}

Thermal analyses at selected alloy compositions $\left(0.05 \leq x_{\mathrm{Sr}} \leq 0.30\right)$ were conducted at various heating rates of 7-20 $\mathrm{K} \mathrm{min}^{-1}$. In Figure 9, a representative thermmogram is presented at $7 \mathrm{~K} \mathrm{~min}^{-1}$. At mole fractions up to $x_{\mathrm{Sr}}=0.25$, two major transition temperatures were apparent: one related to the melting of $\mathrm{Bi}$ phase at $\sim 543( \pm 2) \mathrm{K}$ and the other to the liquidus (liquid = liquid $+\mathrm{SrBi}_{3}$ ). The measured melting temperature of $\mathrm{Bi}$ was in excellent agreement with the 
melting temperature of pure bismuth at $544 \mathrm{~K}$. The phase transition temperatures determined by DSC and emf measurements are summarized in Table 4. The liquidus temperatures determined by emf measurements and thermal analysis agree within $7 \mathrm{~K}$.

At $x_{\mathrm{Sr}}=0.30$, three transition temperatures were observed: the first at $543 \mathrm{~K}$ is related to the melting of meta-stable $\mathrm{Bi}$ in accordance with the XRD measurements, the liquidus transition at $\sim 917 \mathrm{~K}$, and the solidus transition at $\sim 843 \mathrm{~K}$ (Figure 9). During the solidus transition, the following two reactions are probable: [liquid $+\mathrm{Sr}_{2} \mathrm{Bi}_{3}=\mathrm{SrBi}_{3}+\mathrm{Sr}_{2} \mathrm{Bi}_{3}$ ] or [liquid $+\mathrm{Sr}_{11} \mathrm{Bi}_{10}=$ $\left.\mathrm{SrBi}_{3}+\mathrm{Sr}_{2} \mathrm{Bi}_{3}\right]$

\section{[Figure 9]}

\section{[Table 4]}

\subsection{Comparison with equilibrium phase diagram}

Based on the phase transition temperatures determined by DSC, XRD, and emf measurements, these results were compared with the existing equilibrium phase diagram calculated by Okamoto and Wang [5,17], as shown in Figure 10 [18]. The liquidus temperatures of Sr-Bi alloys at mole fractions $x_{\mathrm{Sr}}<0.40$ agreed with our measurements within $10 \mathrm{~K}$. In this work, we identified two additional phases of $\mathrm{Sr}_{2} \mathrm{Bi}_{3}$, and $\mathrm{Sr}_{4} \mathrm{Bi}_{3}$ (dashed lines in Figure 10) using XRD.

At high mole fractions $\left(x_{\mathrm{Sr}} \geq 0.40\right)$, the observed transition temperatures by emf technique deviated substantially from the reported transition temperatures up to $23 \mathrm{~K}$ difference. In general, the discrepancy is primarily due to the non-equilibrium phases present in these $\mathrm{Sr}-\mathrm{Bi}$ alloys, evidenced by the presence of meta-stable phases at these compositions (e.g., $\mathrm{Sr}_{5} \mathrm{Bi}_{3}, \mathrm{Sr}_{2} \mathrm{Bi}$, and $\mathrm{Sr}_{4} \mathrm{Bi}_{3}$ at $\left.x_{\mathrm{Sr}}=0.65\right)$ and by the absence of pure $\mathrm{Sr}$ phase at $x_{\mathrm{Sr}}>0.67$. 
At $x_{\mathrm{Sr}}=0.40$ and 0.45 , this work observed the transition temperature at $\sim 906 \mathrm{~K}$ while the equilibrium temperature was calculated to be $883 \mathrm{~K}$ ( $23 \mathrm{~K}$ difference). This difference can be explained, in part, by the presence of the $\mathrm{Sr}_{2} \mathrm{Bi}_{3}$ phase that is not considered in the equilibrium phase diagram calculation and/or the strong tendency to form non-equilibrium phases. However, Wang et al. attributed this invariant temperature to be the peritectic reaction [liquid $+\mathrm{Sr}_{5} \mathrm{Bi}_{3}=$ $\left.\mathrm{Sr}_{11} \mathrm{Bi}_{10}\right]$; Okamoto described this as the allotropic reaction $\left[\alpha \mathrm{Sr}_{11} \mathrm{Bi}_{10}=\beta \mathrm{Sr}_{11} \mathrm{Bi}_{10}\right]$. These discrepancies invite a scrutiny into the phase behavior of the Sr-Bi system, possibly through advanced computational and careful experimental approaches.

\section{[Figure 10]}

\section{CONCLUSIONS}

This study has determined thermodynamic properties of the binary $\mathrm{Sr}-\mathrm{Bi}$ system, including activities, partial molar entropies, enthalpies, and excess Gibbs energies. The liquidstate solubility of $\mathrm{Sr}$ in $\mathrm{Bi}$ was estimated to be $\sim 15 \mathrm{~mol} \%$ at $788 \mathrm{~K}$ and $\sim 40 \mathrm{~mol} \%$ at $988 \mathrm{~K}$. At high $\mathrm{Sr}$ compositions $\left(x_{\mathrm{Sr}} \geq 0.25\right)$, strong non-equilibrium phase behavior was observed; for example, three phases in the binary system and the absent pure Sr phase at $x_{\mathrm{Sr}}>0.67$. In addition, two additional phases of $\mathrm{Sr}_{2} \mathrm{Bi}_{3}$ and $\mathrm{Sr}_{4} \mathrm{Bi}_{3}$ were considered in describing the phase behavior of Sr-Bi system, which are not considered in the most recent Sr-Bi equilibrium phase diagram.

Combining the high liquid-state solubility and the strong chemical interactions between

$\mathrm{Sr}$ and $\mathrm{Bi}\left(a_{\mathrm{Sr}}\right.$ as low as $\left.1.2 \times 10^{-13}\right)$, Bi shows promise as an electrode material for separating dissolved strontium ions $\left(\mathrm{Sr}^{2+}\right)$ from molten salt electrolytes (e.g., $\left.\mathrm{LiCl}-\mathrm{KCl}-\mathrm{SrCl}_{2}\right)$. 


\section{Author Contributions}

The manuscript was written through contributions of all authors. All authors have given approval to the final version of the manuscript.

\section{Funding Sources}

US Department of Energy, Office of Nuclear Energy

\section{ACKNOWLEDGEMENTS}

The author would like to acknowledge Cassie Marker for discussions regarding thermodynamic modeling. This work is supported by the US Department of Energy, Office of Nuclear Energy's Nuclear Engineering University Program (Award No. DE-NE0008425) and Integrated University Program Graduate Fellowship (Award No. DE-NE0000113). 


\section{REFERENCES}

[1] Electrometallurgical Techniques for DOE Spent Fuel Treatment: Final Report, National Academy Press, Washington, D.C, 2000.

[2] M.F. Simpson, Projected Salt Waste Production from a Commercial Pyroprocessing Facility, Science and Technology of Nuclear Installations (2013) Article number: 945858.

[3] J. Bruno, R.C. Ewing, Spent nuclear fuel, Elements. 2 (2006) 343-349.

[4] H. Kim, N. Smith, K. Kumar, T. Lichtenstein, Electrochemical Separation of Barium into Liquid Bismuth by Controlling Deposition Potentials, Electrochim. Acta. 220 (2016) 237 244.

[5] H. Okamoto, Supplemental Literature Review of Binary Phase Diagrams: Al-Mg, Bi-Sr, Ce-Cu, Co-Nd, Cu-Nd, Dy-Pb, Fe-Nb, Nd-Pb, Pb-Pr, Pb-Tb, Pd-Sb, and Si-W, JPEDAV. 36 (2015) 183-195.

[6] H. Kim, D.A. Boysen, D.J. Bradwell, B. Chung, K. Jiang, A.A. Tomaszowska, K. Wang, W. Wei, D.R. Sadoway, Thermodynamic properties of calcium-bismuth alloys determined by emf measurements, Electrochim. Acta. 60 (2011) 154-162.

[7] S. Poizeau, H. Kim, J.M. Newhouse, B.L. Spatocco, D.R. Sadoway, Determination and modeling of the thermodynamic properties of liquid calcium-antimony alloys, Electrochim. Acta. 76 (2012) 8-15.

[8] J.M. Newhouse, S. Poizeau, H. Kim, B.L. Spatocco, D.R. Sadoway, Thermodynamic properties of calcium-magnesium alloys determined by emf measurements, Electrochim. Acta. 91 (2013) 293-301.

[9] J. Delcet, J.J. Egan, Thermodynamics of Liquid Ca-Agand Ca-In Alloys, J. Less-Common 
Met. Elsevier Sequoia S.A. 59 (1978) 229-236.

[10] J. Fouletier, H. Seinera, M. Kleitz, J. Delcet, R.J. Heus, J.J. Egan, Electronic Conductivity in Solid CaF at High Temperature, J. Solid State Chem. J. Appl. Electrochem. This J. J. Chim. Phys. J. Appl. Electrochem. J. Solid State Chem. J. Fouletier J. Solid State Chem. 125 (1976) 369-217.

[11] N.I. Sorokin, B.P. Sobolev, Solid-State Fluoride Electrolyte Review, Crystallogr. Reports. 52 (2007) 842-863.

[12] HSC Chemistry 5.1, F. Outokumpu Research Oy, Finland, 2002.

[13] G.W.H. Hohne, W.F. Hemminger, H.-J. Flammersheim, Differential Scanning Calorimetry, $2^{\text {nd }}$ Ed., Springer-Verlag Berlin Heidelberg, 2003.

[14] R.T. Downs, M. Hall-Wallace, The American Mineralogist Crystal Structure Database, (2003) American Mineralogist 88, 247-250.

[15] G. Bergerhoff, I.D. Brown, Inorganic Crystal Structure Database (FIZ Karlsruhe), (1978).

[16] H. Okamoto, Bi-Sr (Bismuth-Strontium), Binary Alloy Phase Diagrams, $2^{\text {nd }}$ Ed. ASM International. 1990.

[17] Y. Wang, J. Xin, C. Chen, S. Liu, B. Hu, Y. Du, Thermodynamic assessment of the Sr-In and Sr-Bi systems supported by first-principles calculations, Calphad. 45 (2014) 49-54.

[18] J.O. Andersson, T. Helander, L. Hoglund, P.F. Shi, B. Sundman, Thermo-Calc and DICTRA, Computational tools for materials science, Calphad. 26 (2002) 273-312. 


\section{TABLES AND FIGIRES}

Table 1. Measured partial molar entropies and partial molar enthalpies for $\mathrm{Sr}-\mathrm{Bi}$ alloy compositions $x_{\mathrm{Sr}}=0.05$ to $x_{\mathrm{Sr}}=0.75$ as well as linear fits of emf values.

\begin{tabular}{cccccc}
\hline$x_{S r}$ & $T(\mathrm{~K})$ & $\partial E_{\text {cell }} / \partial T\left(\mu \mathrm{V} \mathrm{K}^{-1}\right)$ & $\partial\left(E_{\text {cell }} / T\right) / \partial(1 / T)(\mathrm{mV})$ & $\Delta \bar{S}_{\mathrm{Sr}}\left(\mathrm{J} \mathrm{mol}^{-1} \mathrm{~K}^{-1}\right)$ & $\Delta \bar{H}_{\mathrm{Sr}}\left(\mathrm{kJ} \mathrm{mol}^{-1}\right)$ \\
\hline 0.05 & $728-1007$ & 157 & 883 & 30.3 & -170.4 \\
0.10 & $754-1009$ & 69.2 & 919 & 13.4 & -177.3 \\
0.15 & $786-987$ & 27.7 & 926 & 5.3 & -178.7 \\
0.20 & $835-987$ & 6.4 & 913 & 1.2 & -176.2 \\
0.20 & $786-835$ & -570 & 1395 & -110 & -269.2 \\
0.25 & $883-959$ & 0.8 & 914 & 0.2 & -176.4 \\
0.25 & $782-883$ & -602 & 1469 & -116 & -283.5 \\
0.30 & $908-984$ & -40.7 & 904 & -7.9 & -174.4 \\
0.30 & $831-908$ & -611 & 1423 & -118 & -274.6 \\
0.30 & $782-831$ & -133 & 1023 & -25.7 & -197.4 \\
0.35 & $959-1010$ & -76.6 & 964 & -14.8 & -186.0 \\
0.35 & $831-959$ & -527 & 1327 & -101.7 & -256.1 \\
0.35 & $780-831$ & -181 & 1039 & -34.9 & -200.5 \\
0.40 & $867-1010$ & -508 & 926 & -98 & -178.7 \\
0.40 & $780-867$ & -62 & 1324 & -12 & -255.5 \\
0.45 & $959-1010$ & -519 & 1197 & -100.2 & -231.0 \\
0.45 & $780-959$ & -94.7 & 928 & -18.3 & -179.1 \\
0.50 & $983-1009$ & -292 & 1111 & -56.3 & -214.4 \\
0.50 & $779-983$ & -108 & 931 & -20.8 & -179.7 \\
0.55 & $984-1009$ & -346 & 1167 & -66.8 & -225.2 \\
0.55 & $779-984$ & -100 & 925 & -19.3 & -178.5 \\
0.65 & $804-1007$ & -422 & 1169 & -81.4 & -225.6 \\
0.75 & $933-1009$ & -2200 & 2725 & -424.5 & -525.8 \\
0.75 & $830-933$ & -676 & 1265 & -130.4 & -244.1 \\
\hline
\end{tabular}


Table 2. Measured emf, natural $\log$ of the activity of $\mathrm{Sr}$ in $\mathrm{Bi}$, and the measured excess partial molar Gibbs energy of strontium of $x_{\mathrm{Sr}}=0.05$ to $x_{\mathrm{Sr}}=0.75$.

\begin{tabular}{c|ccc|ccc|ccc}
\hline & \multicolumn{3}{|c|}{$E(\mathrm{~V})$} & \multicolumn{3}{c|}{$\ln a_{\mathrm{Sr}}$} & \multicolumn{3}{c}{$\bar{G}_{\mathrm{Sr}}^{E}\left(\mathrm{~kJ} \mathrm{~mol}^{-1}\right)$} \\
$x_{\mathrm{Sr}}$ & $788 \mathrm{~K}$ & $888 \mathrm{~K}$ & $988 \mathrm{~K}$ & $788 \mathrm{~K}$ & $888 \mathrm{~K}$ & $988 \mathrm{~K}$ & $788 \mathrm{~K}$ & $888 \mathrm{~K}$ & $988 \mathrm{~K}$ \\
\hline 0.05 & 1.008 & 1.024 & 1.039 & -29.7 & -26.8 & -24.4 & -175 & -176 & -176 \\
0.10 & 0.976 & 0.982 & 0.989 & -28.7 & -25.7 & -23.2 & -173 & -173 & -172 \\
0.15 & 0.948 & 0.951 & 0.953 & -27.9 & -24.9 & -22.4 & -170 & -170 & -168 \\
0.20 & 0.946 & 0.919 & 0.920 & -27.9 & -24.0 & -21.6 & -172 & -165 & -164 \\
0.25 & 0.946 & 0.891 & 0.891 & -27.9 & -23.3 & -20.9 & -174 & -162 & -160 \\
0.30 & 0.919 & 0.881 & 0.864 & -27.1 & -23.0 & -20.3 & -170 & -161 & -157 \\
0.35 & 0.912 & 0.879 & 0.838 & -26.9 & -23.0 & -19.7 & -169 & -162 & -153 \\
0.40 & 0.878 & 0.880 & 0.829 & -25.9 & -23.0 & -19.5 & -164 & -163 & -153 \\
0.45 & 0.879 & 0.870 & 0.826 & -25.9 & -22.7 & -19.4 & -164 & -162 & -153 \\
0.50 & 0.845 & 0.834 & 0.822 & -24.9 & -21.8 & -19.3 & -159 & -156 & -153 \\
0.55 & 0.845 & 0.835 & 0.824 & -24.9 & -21.8 & -19.4 & -159 & -157 & -154 \\
0.65 & 0.843 & 0.801 & 0.758 & -24.8 & -20.9 & -17.8 & -160 & -151 & -143 \\
0.75 & 0.836 & 0.769 & 0.610 & -24.6 & -20.1 & -14.3 & -159 & -146 & -115 \\
\hline
\end{tabular}


Table 3. Reported crystal structures in Sr-Bi system [14-16].

\begin{tabular}{|c|c|c|c|c|c|c|}
\hline \multirow[t]{2}{*}{ Phase } & \multirow[t]{2}{*}{$x_{\mathrm{Sr}}$} & \multirow{2}{*}{$\begin{array}{l}\text { Space group } \\
\text { (Pearson symbol) }\end{array}$} & \multirow{2}{*}{$\begin{array}{l}\text { Density } \\
\left(\mathrm{mg} \mathrm{m}^{-3}\right)\end{array}$} & \multirow{2}{*}{$\begin{array}{l}\text { Volume } \\
\left(\mathrm{nm}^{3}\right)\end{array}$} & \multicolumn{2}{|c|}{ Lattice parameters } \\
\hline & & & & & $(\mathrm{nm})$ & $\left({ }^{\circ}\right)$ \\
\hline \multirow[t]{3}{*}{$\mathrm{Bi}$} & 0.00 & hR6 & 9.81 & 0.2123 & $a=0.45459$ & $\alpha=90$ \\
\hline & & $R-3 m$ & & & $b=0.45459$ & $\beta=90$ \\
\hline & & & & & $c=1.18623$ & $\gamma=120$ \\
\hline \multirow[t]{3}{*}{$\mathrm{SrBi}_{3}$} & 0.25 & $c P 4$ & 9.26 & 0.12818 & $\mathrm{a}=0.5042$ & $\alpha=90$ \\
\hline & & $P m-3 m$ & & & $b=0.5042$ & $\beta=90$ \\
\hline & & & & & $c=0.5042$ & $\gamma=90$ \\
\hline \multirow[t]{3}{*}{$\mathrm{Sr}_{2} \mathrm{Bi}_{3}$} & 0.40 & $o P 20$ & 7.6 & 0.70069 & $\mathrm{a}=1.5631$ & $\alpha=90$ \\
\hline & & Pnna & & & $b=0.6793$ & $\beta=90$ \\
\hline & & & & & $c=0.6599$ & $\gamma=90$ \\
\hline \multirow[t]{3}{*}{$\mathrm{Sr}_{11} \mathrm{Bi}_{10}$} & 0.52 & $t I 84$ & 6.76 & 2.9993 & $\mathrm{a}=1.2765$ & $\alpha=90$ \\
\hline & & $I 4 / \mathrm{mmm}$ & & & $b=1.2765$ & $\beta=90$ \\
\hline & & & & & $\mathrm{c}=1.8407$ & $\gamma=90$ \\
\hline \multirow[t]{3}{*}{$\mathrm{Sr}_{4} \mathrm{Bi}_{3}$} & 0.57 & $c I 28$ & 6.3 & 1.0306 & $\mathrm{a}=1.0101$ & $\alpha=90$ \\
\hline & & $I-43 d$ & & & $\mathrm{~b}=1.0101$ & $\beta=90$ \\
\hline & & & & & $\mathrm{c}=1.0101$ & $\gamma=90$ \\
\hline \multirow[t]{3}{*}{$\mathrm{Sr}_{5} \mathrm{Bi}_{3}$} & 0.63 & $h P 16$ & 5.77 & 0.61278 & $a=0.963$ & $\alpha=90$ \\
\hline & & $\mathrm{PG}_{3} / \mathrm{mcm}$ & & & $\mathrm{b}=0.963$ & $\beta=90$ \\
\hline & & & & & $c=0.763$ & $\gamma=120$ \\
\hline \multirow[t]{3}{*}{$\mathrm{Sr}_{2} \mathrm{Bi}$} & 0.67 & $t I 12$ & 5.75 & 0.44377 & $\mathrm{a}=0.501$ & $\alpha=90$ \\
\hline & & $I 4 / \mathrm{mmm}$ & & & $b=0.501$ & $\beta=90$ \\
\hline & & & & & $c=1.768$ & $\gamma=90$ \\
\hline \multirow[t]{3}{*}{$\mathrm{Sr}(\mathrm{rt})$} & 1.00 & $c F 4$ & 2.58 & 0.2253 & $a=0.60849$ & $\alpha=90$ \\
\hline & & $F m-3 m$ & & & $b=0.60849$ & $\beta=90$ \\
\hline & & & & & $c=0.60849$ & $\gamma=90$ \\
\hline \multirow[t]{3}{*}{$\mathrm{Sr}(\mathrm{ht})$} & 1.00 & $c I 2$ & 2.55 & 0.1141 & $a=0.485$ & $\alpha=90$ \\
\hline & & $I m-3 m$ & & & $\mathrm{~b}=0.485$ & $\beta=90$ \\
\hline & & & & & $c=0.485$ & $\gamma=90$ \\
\hline
\end{tabular}


Table 4. Summary of transition temperatures determined by emf and DSC techniques.

\begin{tabular}{|c|c|c|c|c|}
\hline \multirow{2}{*}{$x_{\mathrm{Sr}}$} & \multicolumn{2}{|c|}{$T_{\text {solidus }}(\mathrm{K})$} & \multicolumn{2}{|c|}{$T_{\text {liquidus }}(\mathrm{K})$} \\
\hline & Emf & / DSC & Emf & / DSC \\
\hline 0.05 & - & $/ 543$ & 706 & $1-$ \\
\hline 0.10 & - & $/ 543$ & 744 & $/ 745$ \\
\hline 0.15 & - & / 543 & 786 & / 786 \\
\hline 0.20 & - & / 543 & 835 & / 833 \\
\hline 0.25 & - & / 543 & 880 & $/ 873$ \\
\hline 0.30 & 841 & / 843 & 912 & / 917 \\
\hline 0.35 & 843 & $1-$ & 955 & $1-$ \\
\hline 0.40 & 908 & $1-$ & - & $1-$ \\
\hline 0.45 & 908 & I - & - & $1-$ \\
\hline 0.50 & 979 & $1-$ & - & $1-$ \\
\hline 0.55 & 984 & $1-$ & - & $1-$ \\
\hline 0.75 & 929 & $1-$ & - & $1-$ \\
\hline
\end{tabular}




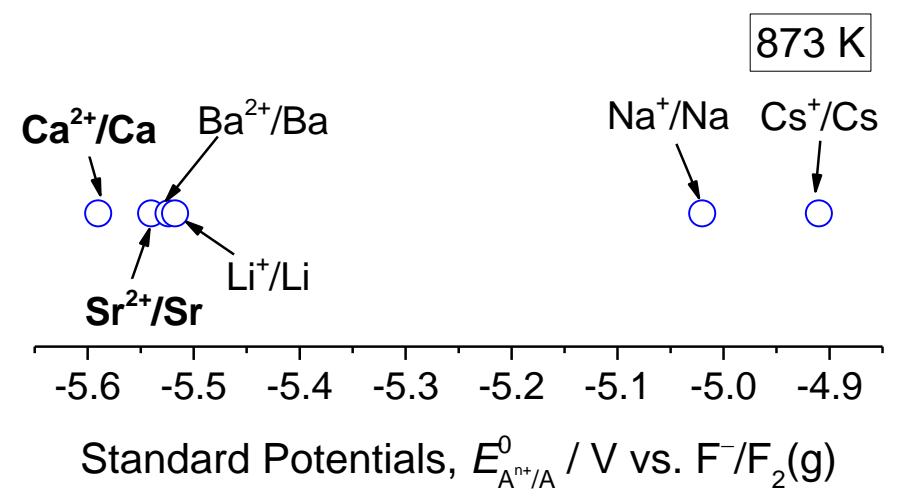

Figure 1a

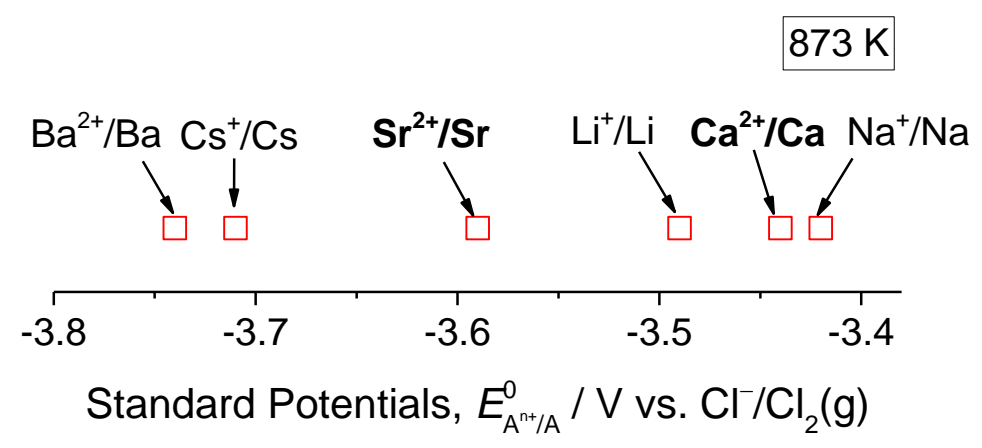

Figure 1b

Figure 1. Comparison of standard electrode potentials of selected alkaline/alkaline-earth elements, calculated using the standard free energies of formation of (a) pure fluorides and (b) pure chlorides at $873 \mathrm{~K} \mathrm{[12].}$ 


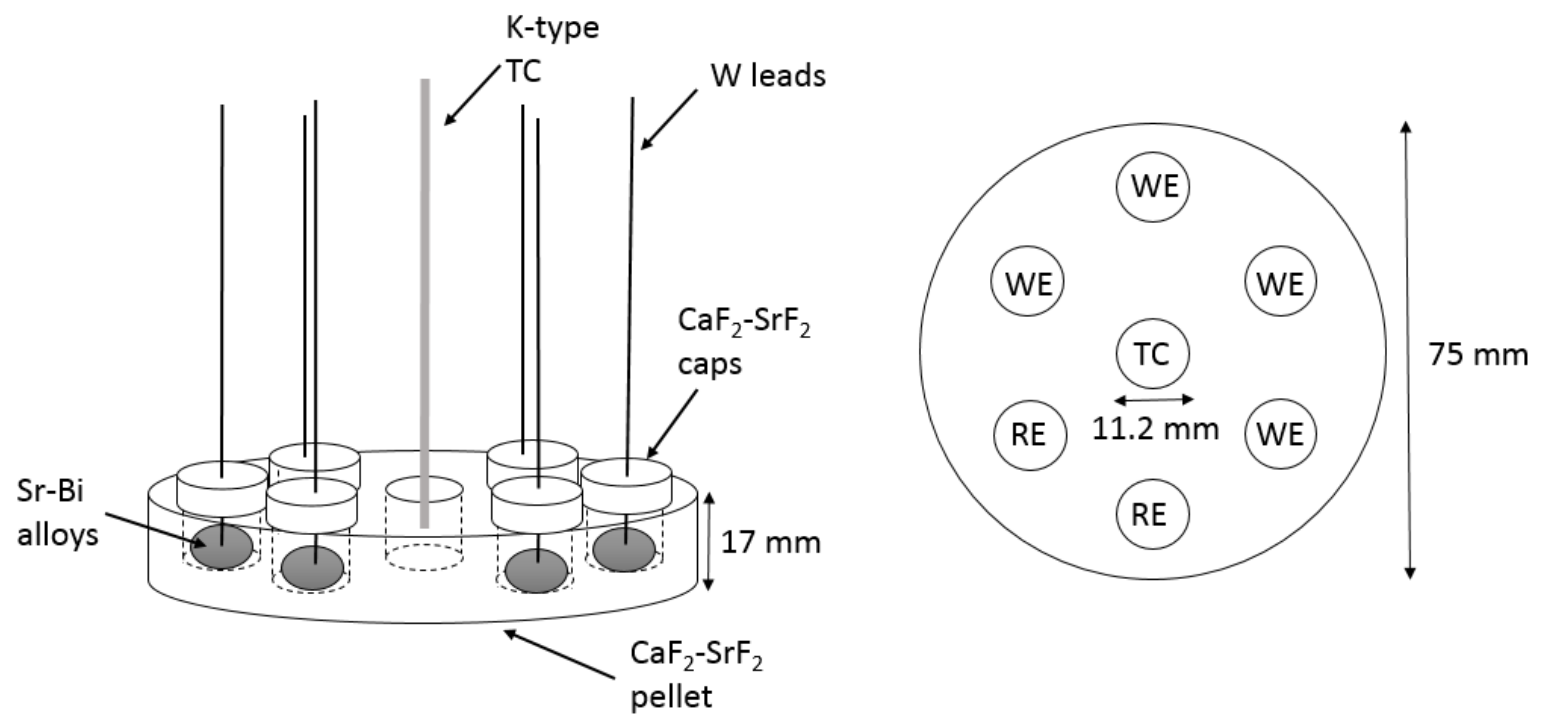

Figure 2a

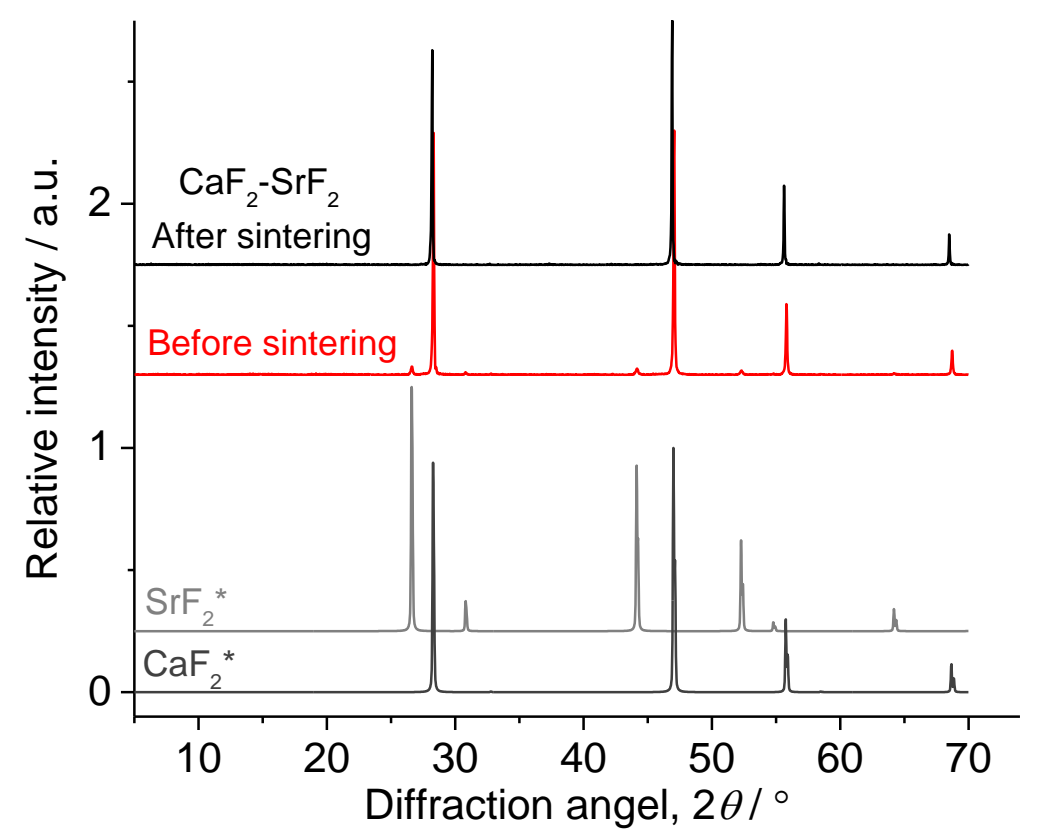

Figure 2b

Figure 2. (a) Schematic electrochemical cell design from side and top views with approximate dimensions and (b) XRD spectra (normalized to the most intense peak for each spectrum) of $\mathrm{CaF}_{2}-\mathrm{SrF}_{2}$ electrolyte before and after the sintering, compared with pure (*) $\mathrm{CaF}_{2}$ and $\mathrm{SrF}_{2}$ diffraction patterns [14]. 


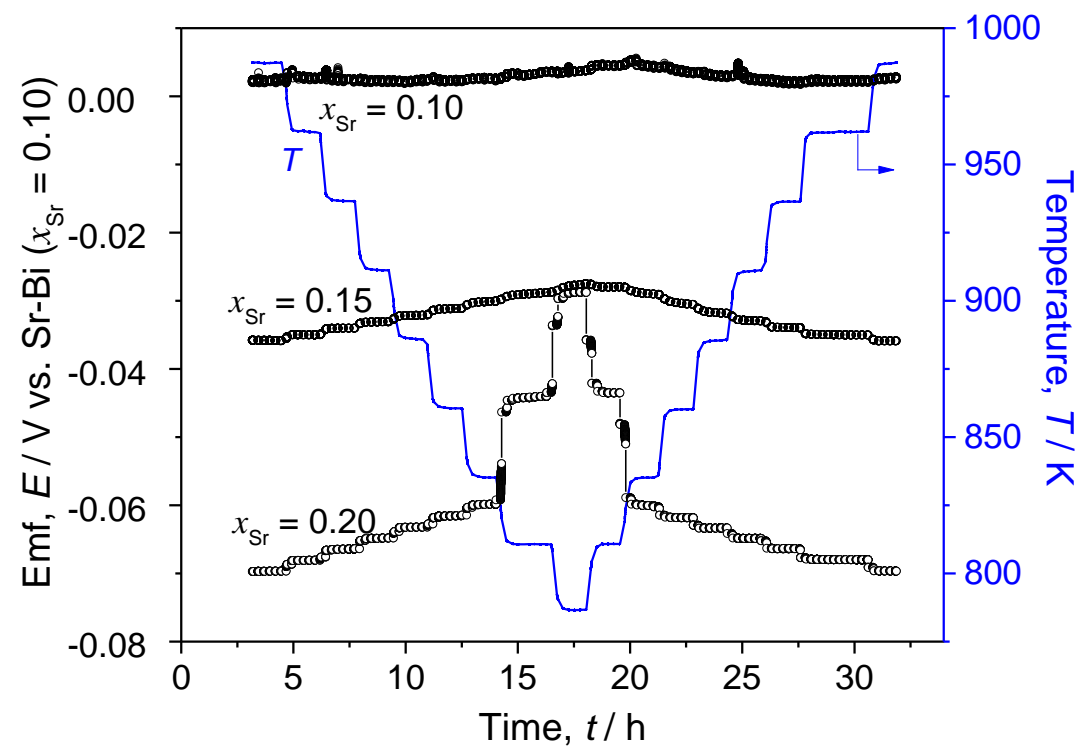

Figure 3a

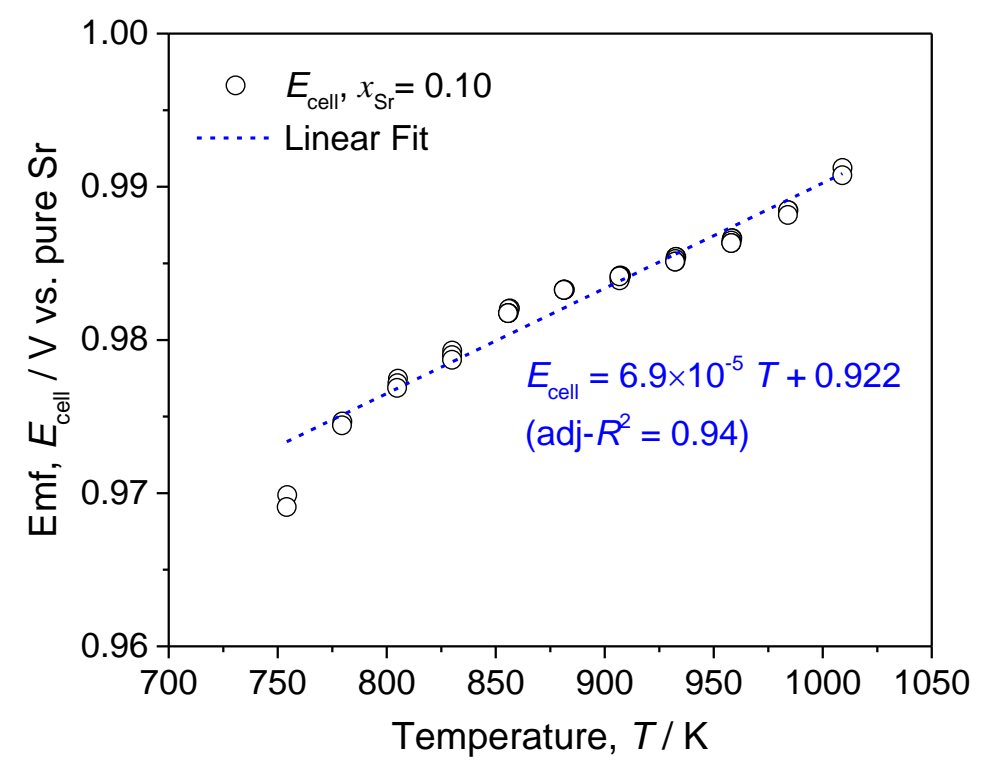

Figure 3b

Figure 3. (a) Emf values and temperature measured as a function of time upon cooling and heating a Sr-Bi $\left(x_{\mathrm{Sr}}=0.10\right)\left|\mathrm{CaF}_{2}-\mathrm{SrF}_{2}(\mathrm{~s})\right| \mathrm{Sr}(\mathrm{in} \mathrm{Bi})$ cell with $\mathrm{Sr}-\mathrm{Bi}$ alloys $x_{\mathrm{Sr}}=0.10,0.15$, and 0.20 and (b) emf values as a function of temperature obtained from $\operatorname{Sr}(\mathrm{s})\left|\mathrm{CaF}_{2}-\mathrm{SrF}_{2}(\mathrm{~s})\right| \operatorname{Sr}-\mathrm{Bi}\left(x_{\mathrm{Sr}}=\right.$ $0.10)$. 


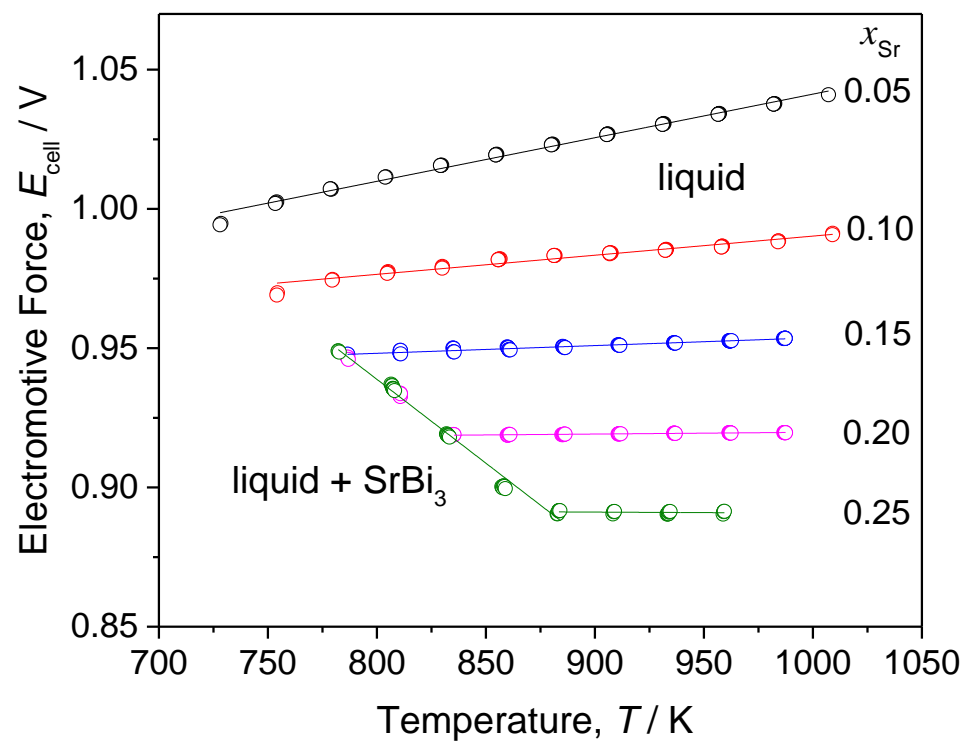

Figure 4a

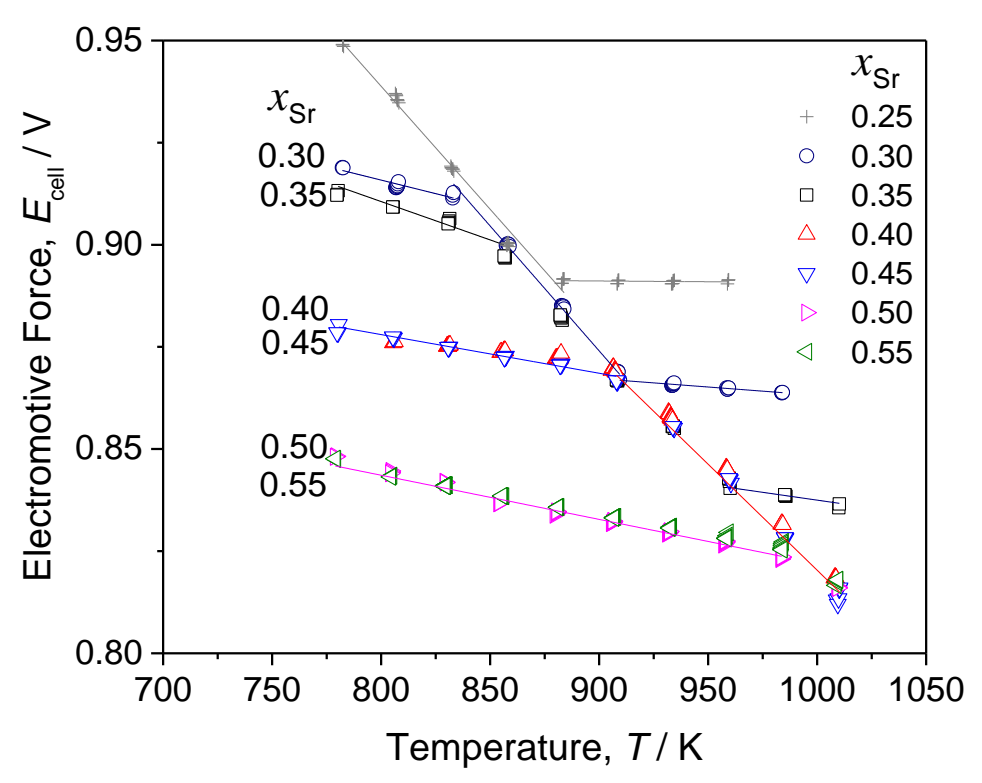

Figure 4b 


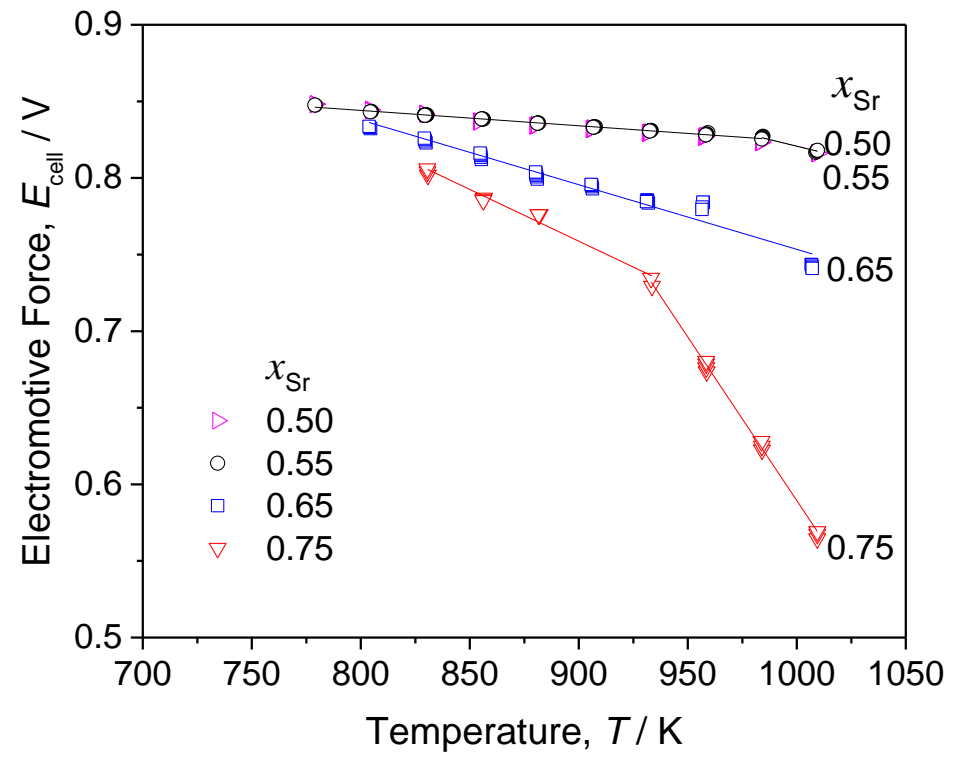

Figure 4c

Figure 4. Emf values of various $\mathrm{Sr}-\mathrm{Bi}$ alloys versus pure $\mathrm{Sr}, E_{\text {cell }}$, as a function of temperature for (a) $x_{\mathrm{Sr}}=0.05$ to $x_{\mathrm{Sr}}=0.25$, (b) $x_{\mathrm{Sr}}=0.25$ to $x_{\mathrm{Sr}}=0.55$, and (c) $x_{\mathrm{Sr}}=0.50$ to $x_{\mathrm{Sr}}=0.75$. 


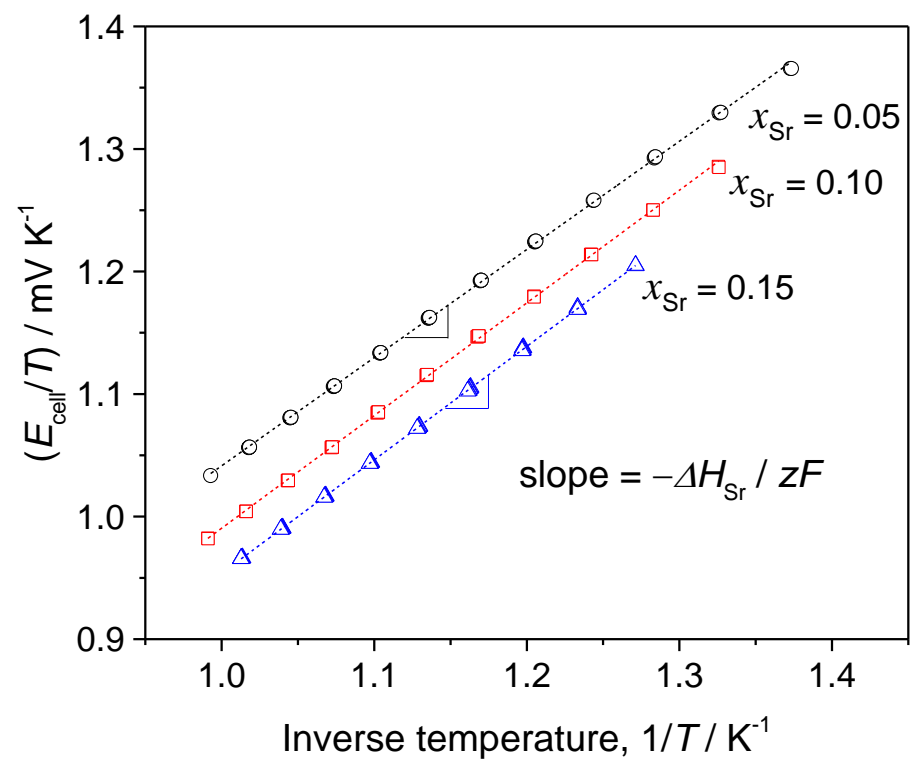

Figure 5. Graphical representation of $E_{\text {cell }} / T$ vs. $1 / T$ to estimate the change in partial molar enthalpy of alloys $x_{\mathrm{Sr}}=0.05-0.15$, where the slope is $-\Delta \bar{H}_{\mathrm{Sr}} / z F$ at each composition. 


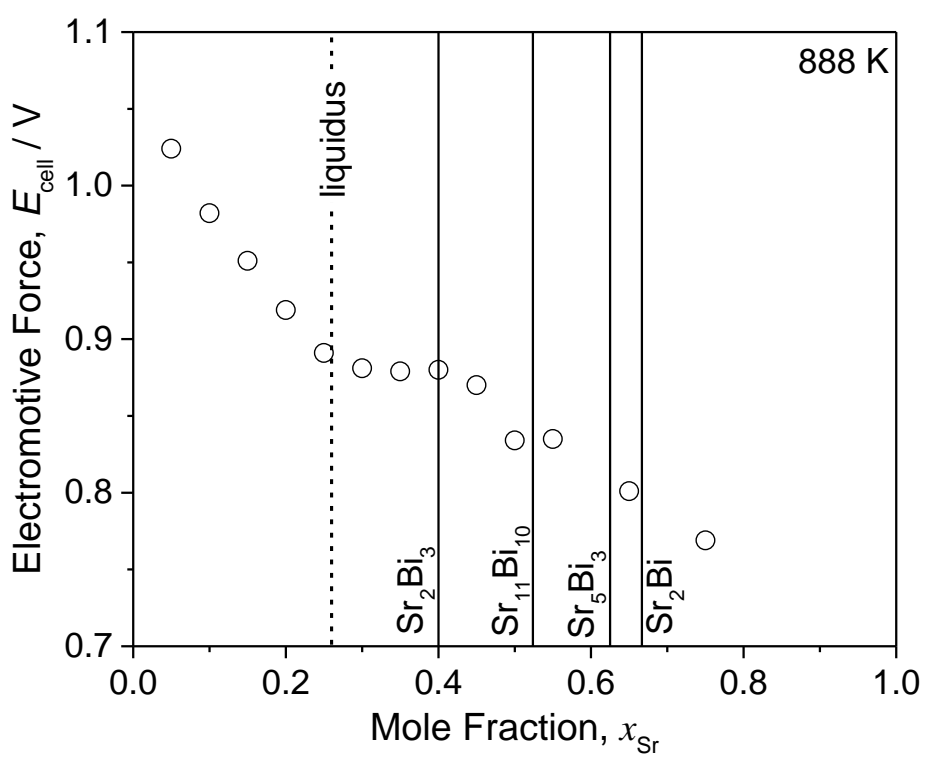

Figure 6a

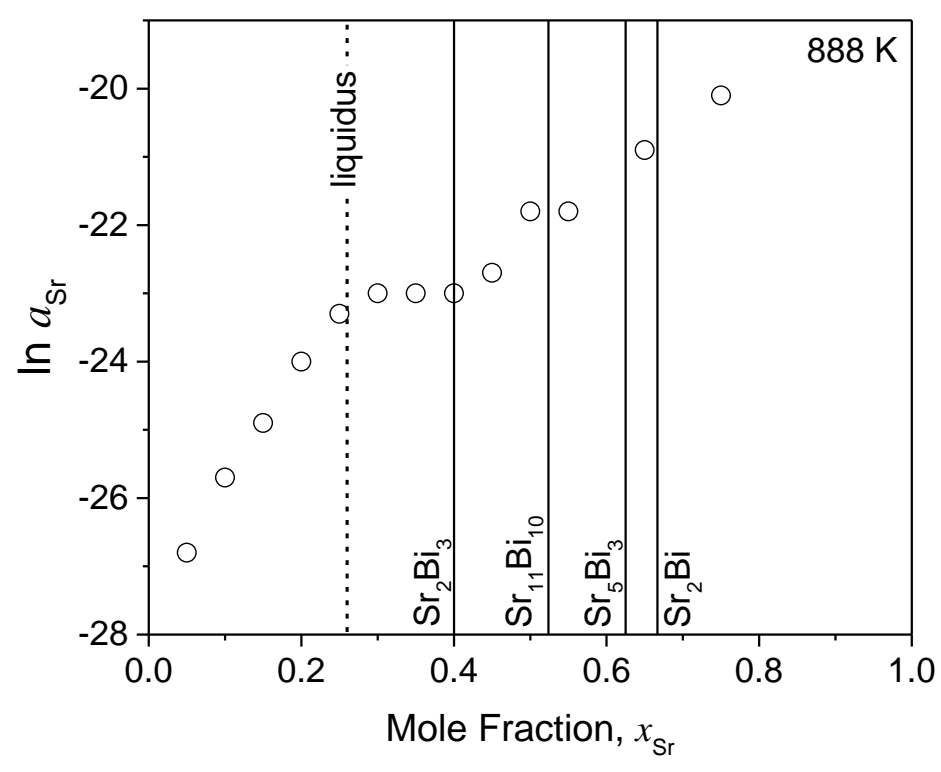

Figure 6b 


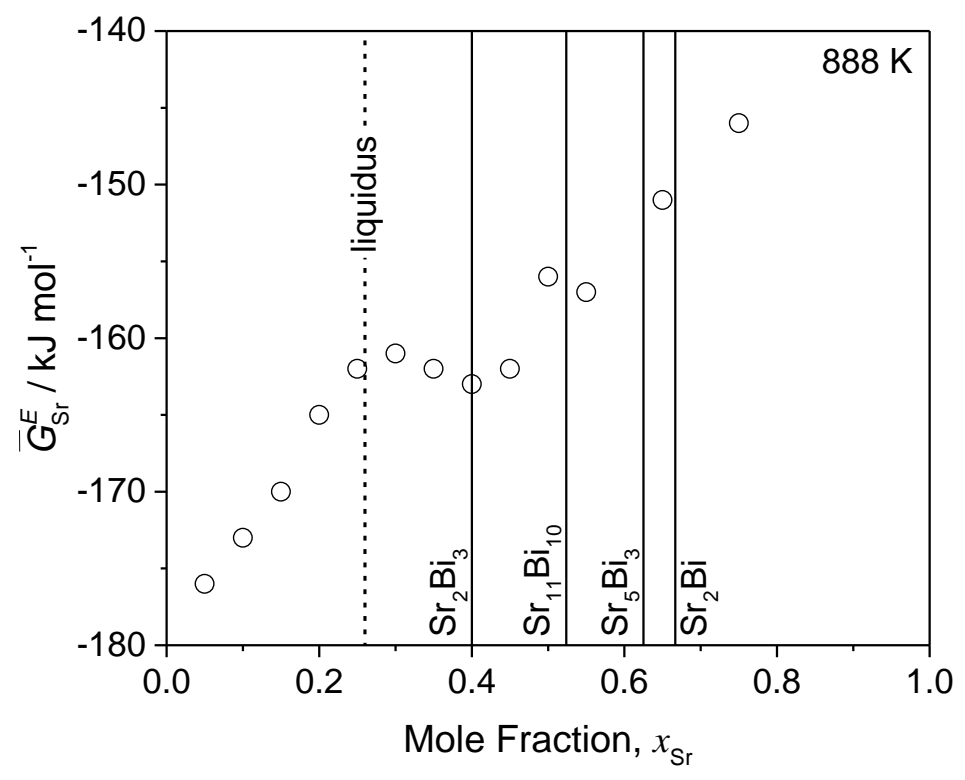

Figure 6c

Figure 6. (a) Measured emf values $\left(E_{\text {cell }}\right)$, (b) natural $\log$ of activity of strontium $\left(\ln a_{\mathrm{Sr}}\right)$, and (c) excess partial molar Gibbs energy $\left(\bar{G}_{\mathrm{Sr}}^{E}\right)$ as a function of mole fraction $x_{\mathrm{Sr}}$ at $888 \mathrm{~K}$. 


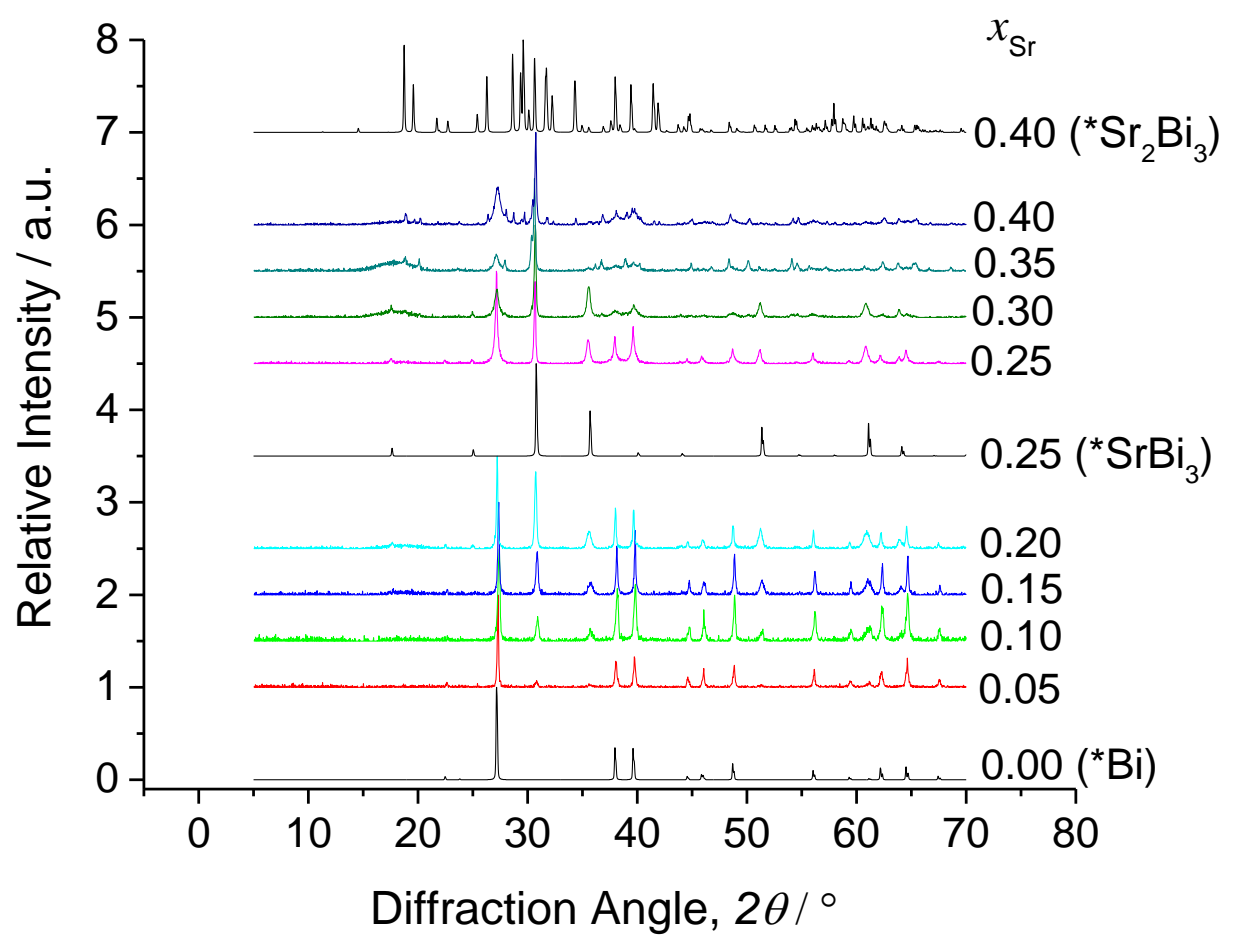

Figure 7a

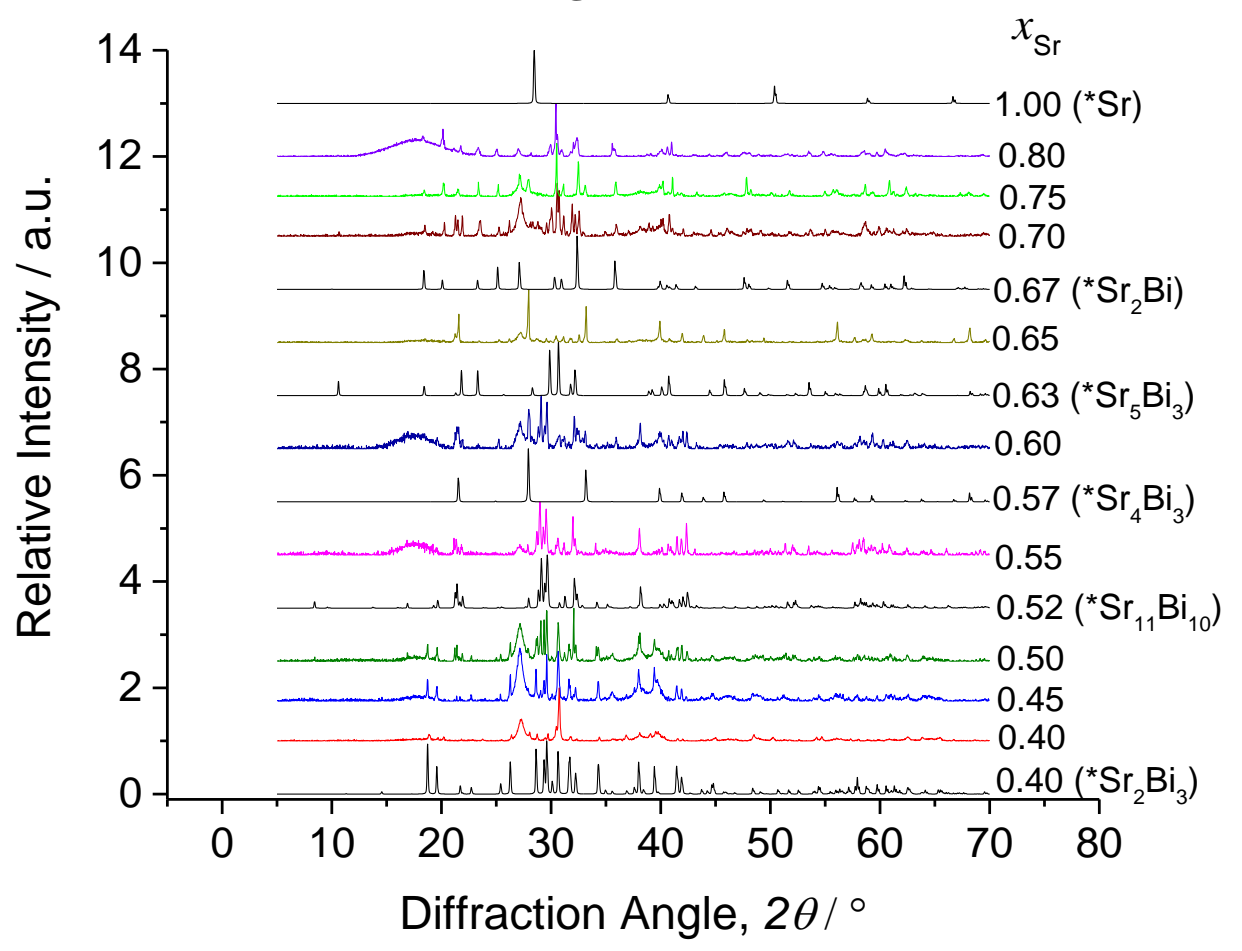

Figure 7b

Figure 7. X-ray diffraction patterns of Sr-Bi alloys (a) $x_{\mathrm{Sr}}=0.00$ to $x_{\mathrm{Sr}}=0.40$ and (b) $x_{\mathrm{Sr}}=0.40$ to $x_{\mathrm{Sr}}=1.00$, compared to the diffraction patterns of Sr-Bi intermetallic compounds $(*)[14,15]$. 


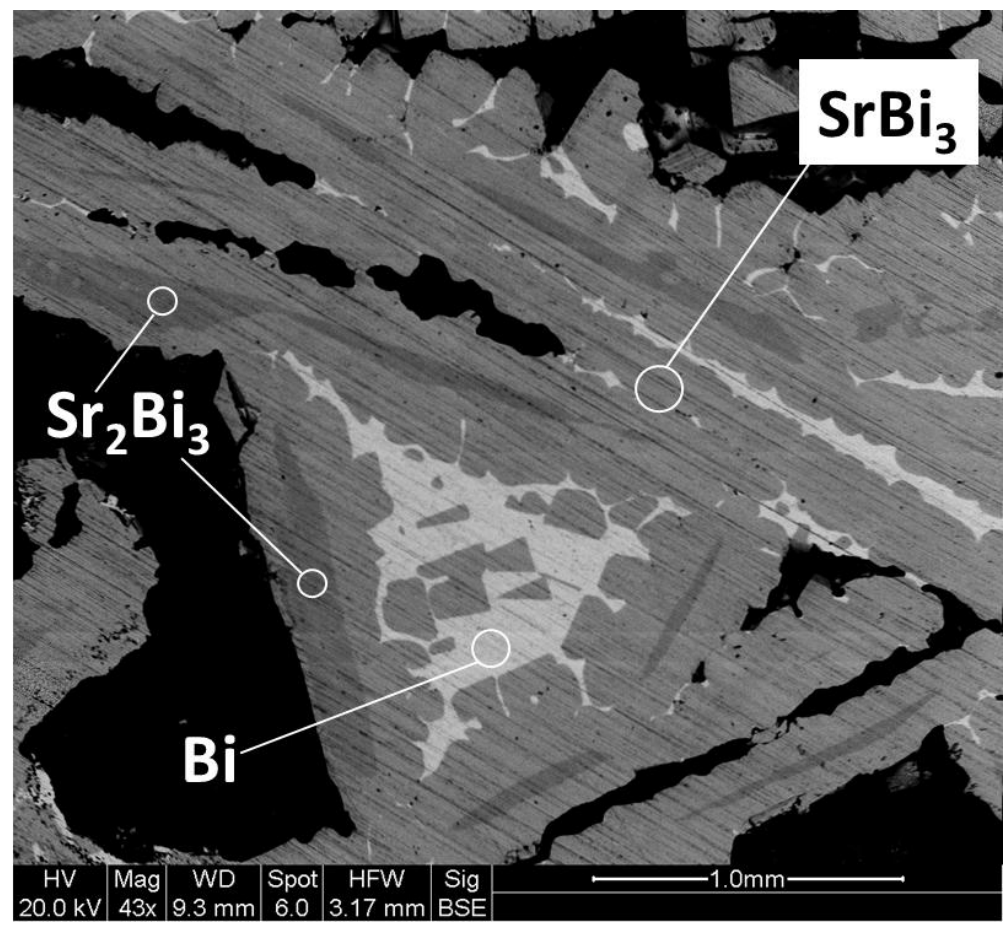

Figure 8. SEM image of $x_{\mathrm{Sr}}=0.25$ alloy that shows the presence of three distinct phases of Bi (bright), $\mathrm{SrBi}_{3}$ (gray), and $\mathrm{Sr}_{2} \mathrm{Bi}_{3}$ (dark gray) based on the chemical analysis by EDS. 


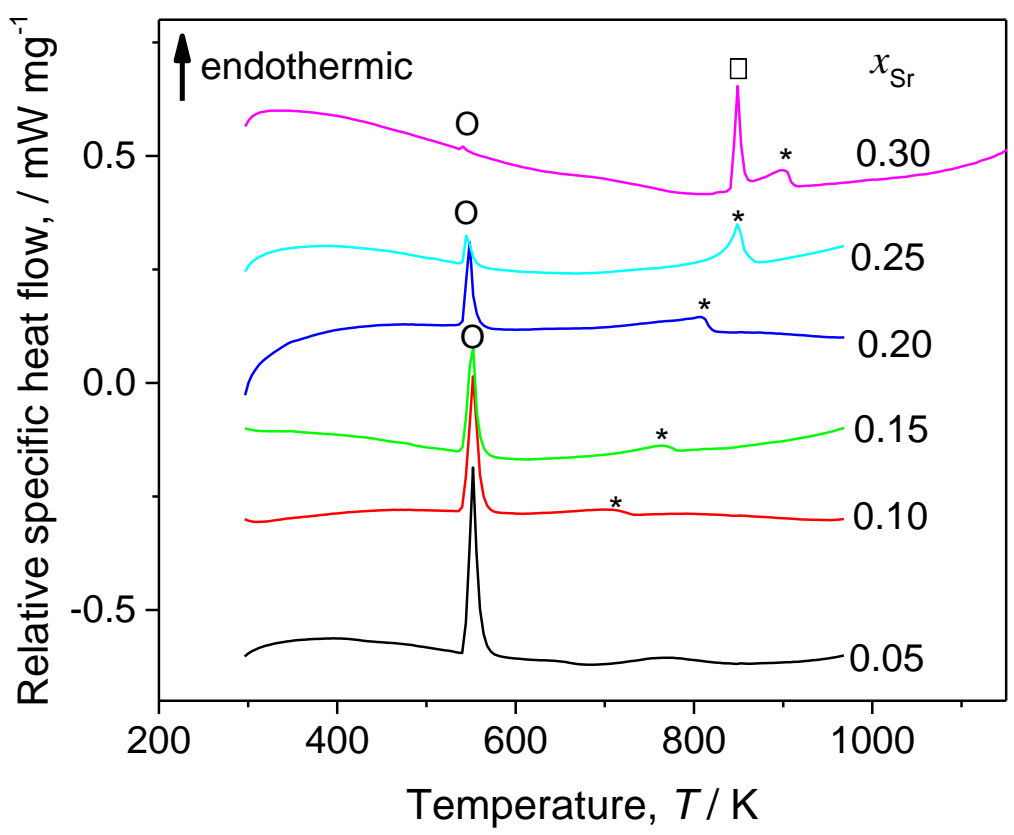

Figure 9. Differential scanning calorimetry data collected upon heating $\mathrm{Sr}$-Bi alloys $x_{\mathrm{Sr}}=0.05$ to $x_{\mathrm{Sr}}=0.30$ at $7 \mathrm{~K} \mathrm{~min}^{-1}$, indicating phase transitions of eutectic temperatures $(\mathrm{O})$, liquidus temperatures $(*)$, and solidus temperature $(\square)$ for $x_{\mathrm{Sr}}=0.30$. 


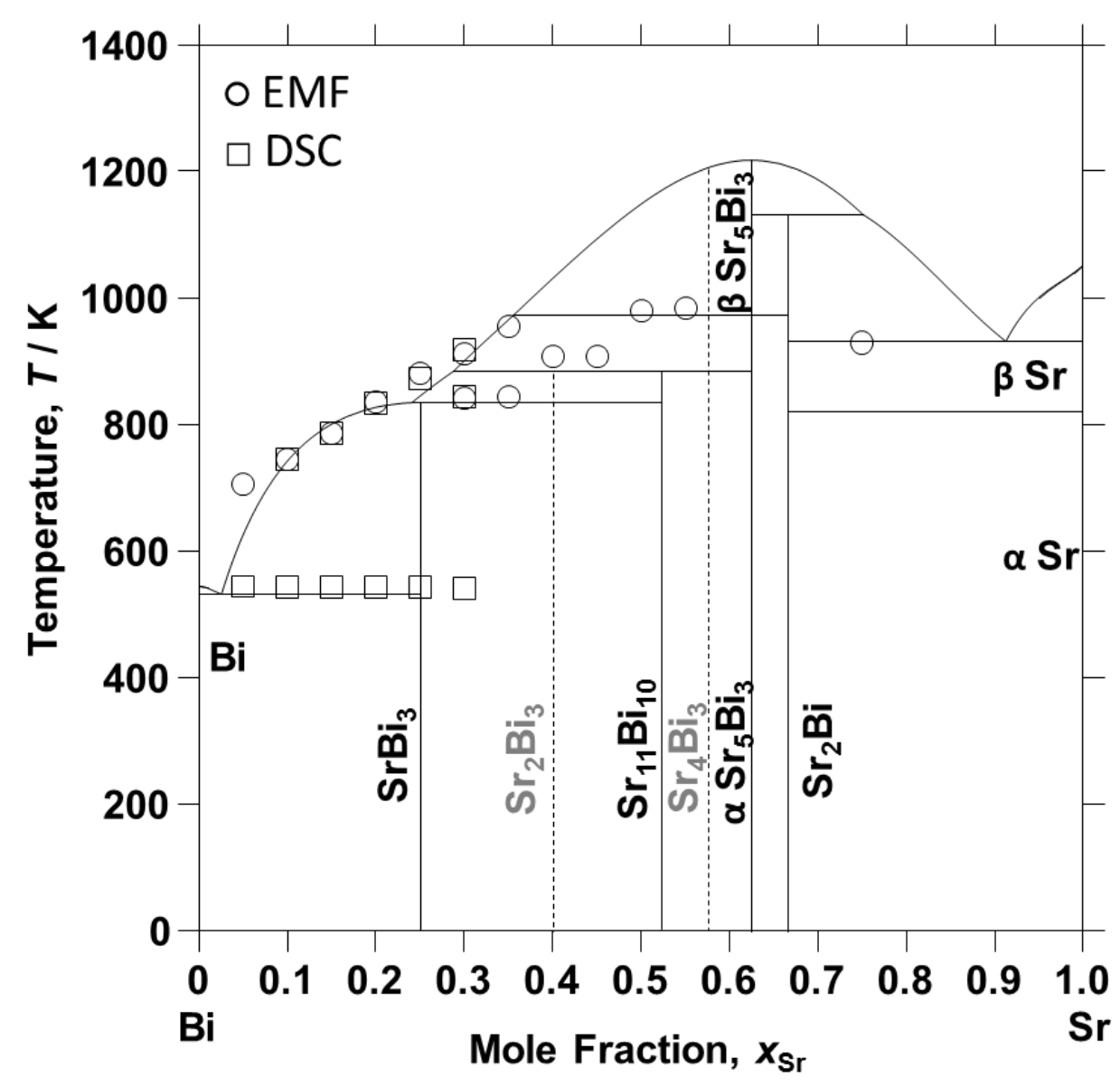

Figure 10. Comparison of experimentally determined phase behavior with the equilibrium phase diagram, adapted from the work by Wang et al. $[17,18]$. The phase transition temperatures were determined by emf measurement ( $\left(\right.$ ) and DSC technique ( $\square$ ). The observed phases of $\mathrm{Sr}_{2} \mathrm{Bi}_{3}$, and $\mathrm{Sr}_{4} \mathrm{Bi}_{3}$ are indicated by dashed lines. Reprinted with permission from Ref. [17]. Copyright 2014 Elsevier. 